\title{
IMPLEMENTING HUMAN RIGHTS IN THE PACIFIC THROUGH NATIONAL HUMAN RIGHTS INSTITUTIONS: THE EXPERIENCE OF FIJI
}

\author{
Catherine Renshaw, Andrew Byrnes and Andrea Durbach*
}

This article discusses the experience of the Fijian Human Rights Commission as an illustration of some of the challenges Pacific nations may face in achieving an independent and effective human rights institution in a complex and sometimes volatile socio-political context. The article argues that the presence of a supportive regional network of national human rights institutions is essential to creating and maintaining independent and effective national institutions.

\section{INTRODUCTION}

In recent years the Governments of a number of the larger Pacific island nations have stated that they wish to create national institutions for the protection and promotion of human rights. ${ }^{2}$ National

1 The research which this article is based on forms part of the Australian Research Council Linkage Project LP0776639 (with the Asia Pacific Forum of National Human Rights Institutions). For further details, see www.ahrcentre.org/. The authors are grateful to Kieren Fitzpatrick and Pip Dargan of the Asia Pacific Forum of National Human Rights Institutions [APF] who provided the authors with access to APF archives during the course of their research. The authors also gratefully acknowledge the valuable contribution of the referee, whose many helpful suggestions have been incorporated in the final version of this article.

* Catherine Renshaw is a research fellow with the Australian Human Rights Centre at the University of New South Wales. Andrew Byrnes is Professor of International Law and Chair of the Management Committee of the Australian Human Rights Centre at the University of New South Wales. Andrea Durbach is Associate Professor and Director of the Australian Human Rights Centre at the University of New South Wales.

2 Examples include: Papua New Guinea Secretary for Community Development Joseph Klapat "Final Option Paper for a Human Rights Commission" The Marianas (17 December 2007) www.mvariety.com (accessed 21 August 2008); the Attorney-General for Samoa undertook to explore the establishment of a national human rights commission in the near future (Strategies for the Future: Protecting Rights in the Pacific Conference, Apia, Samoa, 27-29 April 2008); in 2005 Prime Minister Sir Allan Kemakeza made a statement detailing plans for the establishment of a NHRI with the assistance of the APF; "NHRI Forum" Solomon Star Newspaper (24 February 2005). The Solomon Islands Government sent delegates to the first annual meeting of the APF in Darwin in 1996. 
human rights institutions (NHRIs) are independent bodies established by constitutional or legislative provisions, with a mandate to ensure that states act to protect and take steps to promote a broad range of human rights. The global momentum towards the establishment of NHRIs has until now largely bypassed the Pacific, with the exception of Fiji.

The potential benefits of embedding a dedicated human rights institution within the state are many. In the context of the Pacific, three benefits may be of particular significance. First, members of a national institution are able to work closely with Government in implementing strategies to realise human rights. Secondly, members of the human rights institution are acutely aware of the socio-cultural context into which the panoply of human rights must be translated. Thirdly, there is a sense of ownership in the human rights institution and the principles it embodies by civil society. In a region such as the Pacific, geographic separation with disparate cultures, languages and traditions, these factors have the potential to contribute to a national institution that could effectively, inclusively and gradually inform the human rights culture of a Pacific nation's government and executive.

This article discusses the experience of the Fijian Human Rights Commission (FHRC) as illustrative of some of the challenges Pacific nations may face in achieving an independent and effective human rights institution in a complex and sometimes volatile socio-political context. It argues that the presence of a supportive regional network of national human rights institutions is essential to creating and maintaining independent and effective national institutions. This article considers the FHRC's decision to withdraw its membership from its regional association, the Asia Pacific Forum of National Human Rights Institutions (APF), and from the corresponding international network, the United Nations International Coordinating Committee of Institutions for the Protection and Promotion of Human Rights (ICC), in the wake of the 2006 assumption of military control by Commodore Frank Bainimarama. It considers the factors that led to the APF and ICC questioning the independence of the Fijian Human Rights Commission after the events of 2006 and in this context offers suggestions about ways in which the construction of a national commission (its mandate and composition) might assist in preserving the institution's independence.

\section{THE PARIS PRINCIPLES AND THE ASIA PACIFIC FORUM OF NATIONAL HUMAN RIGHTS INSTITUTIONS}

The burgeoning of NHRIs since the early 1990s has seen the emergence of international and regional networks of national institutions established to support the work of individual institutions through collective action and the sharing of expertise among network members. The most developed and active of these networks has been the APF. The APF is a regional network of NHRIs whose members largely comply, or are in the process of becoming compliant, with the Paris Principles. ${ }^{3}$

3 Principles Relating to the Status and Functioning of National Institutions for the Protection and Promotion of Human Rights UNGA Res 48/134 (20 December 1993) [Paris Principles]. 
The Paris Principles are a set of minimum criteria endorsed by the General Assembly of the United Nations, designed to ensure the independence, effectiveness and pluralistic basis of NHRIs. The APF supports the establishment of new NHRIs in the region and assists in building capacity within existing NHRIs. Future NHRIs established in the Pacific region - such as those foreshadowed in the nations of Samoa, Solomon Islands, and Papua New Guinea, for example - would be eligible to apply for membership of the APF.

The APF acts as a transnational "network" of the sort described by Anne-Marie Slaughter as "a pattern of regular and purposive relations among like government units working across borders." 4 Since its inception in 1996, the APF - whose members include seventeen countries spread geographically from Jordan to Timor-Leste - has convened annually so that its members can consider human rights issues of concern and develop joint solutions to common problems. The network facilitates the exchange of information between members, forges links between staff in different national institutions, and disseminates technological expertise. The APF's achievements are the result of two central network features: the application of a criteria for membership that adheres to international standards and the network's effective operation as a conduit of information.

The criteria for full membership of the APF are adherence to the Paris Principles, which provide that: ${ }^{5}$

A national institution should be given as broad a mandate as possible based on universal human rights

standards;

The institution should be established in a constitutional or legislative text;

The composition of the institution should ensure pluralist representation of society; and

A national institution should have adequate funding to ensure its independence from government.

In the decade or so since its inception, the APF has applied these criteria with a degree of rigour. National institutions that do not comply with the Paris Principles, but which are likely to do so within a relatively short period of time, can become "candidate members" of the APF, while the national institution's members and the state's legislators make the changes needed for the institution to become compliant with the Paris Principles. Associate members are those institutions which currently do not comply with the Paris Principles and are unlikely to do so within a reasonable

4 Anne-Marie Slaughter A New World Order (Princeton, Princeton University Press, 2004) 14.

5 Paris Principles, above n 3. 
period. ${ }^{6}$ The Paris Principles are also the criteria used by the ICC when it accords status to national human rights institutions. ${ }^{7}$

The APF's operation as a conduit of information is particularly important in the Asia Pacific region, where many of the NHRIs function with limited resources and in situations where the independence of the national institution may be susceptible to political interference. Through the APF, members are provided with access to information about best practices and operational efficiencies of other NHRIs in the region. Members are also provided with information about others' competence, integrity and independence. The desire of members to uphold their reputation within the network has led, over time, to the adoption of internal procedures and practices that conform with the expectations of their professional peers. ${ }^{8}$

Many of the challenges faced by Pacific nations, for example: climate change, migrant populations, and the fracturing of cultural links between individuals and societies, are the results of globalisation. Although the dimensions of these challenges are global, in many senses national institutions, not global ones, are well placed to measure and respond to many of the human rights implications of these challenges. National institutions are staffed by the nation's citizens and steeped in the nation's culture and history. Nonetheless, in order to respond to regional and global problems such institutions must be linked - they must be able to share information across borders, to disseminate ideas and address common concerns while still maintaining their national identities. A network, such as APF, provides an answer to the "globalisation paradox": "[p]eople and their governments around the world need global institutions to solve collective problems that can only be addressed on a global scale ... yet world government is both infeasible and undesirable". ${ }^{9}$ Nascent NHRIs in the Pacific region will benefit greatly from engagement with their regional network of NHRIs, the APF, as it enhances the capacity of individual institutions, shares best practices amongst institutions and facilitates co-operation between national institutions.

6 Andrew Byrnes, Andrea Durbach and Catherine Renshaw "Joining the Club: the Asia Pacific Forum of National Human Rights Institutions, the Paris Principles and the advancement of human rights protection in the region" (2008) 14(1) Australian Journal of Human Rights 63; [2008] UNSWLRS 39.

7 The ICC has three categories of membership: 'A' (an institution is compliant with the Paris Principles); ' $\mathrm{B}$ ' (an institution is not fully compliant with the Paris Principles, but has the status of "observer"); or ' $\mathrm{C}$ ' (an institution is not compliant with the Paris Principles). Only 'A' status national institutions have the right to appear before the UN Human Rights Council.

8 Kal Raustiala's discussion of co-operation between network members to achieve positive common outcomes and the increased tendency to conform to common norms over a period of time is helpful in analysing the work of networks such as APF: Kal Raustiala "The Architecture of International Co-operation: Transgovernmental Networks and the Future of International Law" (2002-3) 43 Vanderbilt Journal of International Law 1.

9 Slaughter, above n 4, 8. 
The manner in which the FHRC was established (under the 1997 Constitution of the Republic of Fiji), ${ }^{10}$ its mandate and the selection process for Commissioners, were deemed by the APF and the ICC to accord with the Paris Principles at the inception of the FHRC in 1999. The FHRC was admitted as a full member of the APF in 2000 and received accreditation with the ICC that same year. In the period 2000-2007, the FHRC appears to have been an engaged and active member of its regional network and to have participated fully in the ICC. In 2005, the FHRC represented the APF on the accreditation subcommittee of the ICC. In 2006, the FHRC hosted the eleventh Annual Meeting of the APF in Suva, Fiji.

This article explores the experience of the FHRC and the circumstances which led to questioning by the APF and the ICC of the Commission's continued adherence to the Paris Principles in the turbulent period following the assumption of power by the military in December 2006.

\section{THE CONSTITUTIONAL AND LEGISLATIVE BASIS OF THE FIJI HUMAN RIGHTS COMMISSION}

The FHRC was established under section 42 of the 1997 Constitution of the Republic of the Fiji Islands. Section 42 of the Constitution established the Human Rights Commission and conferred on it three primary functions: to educate the public about the nature and content of the Fiji Bill of Rights, to make recommendations to the Government about matters affecting compliance with human rights and to perform such other functions as are conferred on it by a law made by the Parliament.

Section 42(3) of the Constitution provides that the Human Rights Commission is to consist of three members. The Ombudsman is ex officio one of these members and serves as chairperson of the Commission. The other members of the Human Rights Commission are appointed by the President on the advice of the Prime Minister, following consultation by the Prime Minister with the leader of the Opposition and the sector standing committee of the House of Representatives responsible for matters concerning human rights. ${ }^{11}$ Section 163 of the Constitution provides that the Ombudsman is appointed by the Constitutional Offices Commission following consultation by the Prime Minister. ${ }^{12}$ The Constitutional Offices Commission, consisting of a chairperson and two other

10 Discussed within this paper at Part III, below.

111997 Constitution of Republic of the Fiji Islands, s 42(4) [the Constitution].

12 Ibid, s 163(1). 
members, ${ }^{13}$ is appointed by the President on the nomination of the Minister. ${ }^{14}$ The term of appointment of the Ombudsman (and hence Chairperson of the FHRC) is five years, and he or she is eligible for reappointment. Other members of the Human Rights Commission hold office for two years and are eligible for reappointment for one further term of two years. ${ }^{15}$

Fijian historian Brij Lal, who served as a member of the Constitutional Review Commission (CRC) leading to the adoption of the 1997 Constitution, writes that the adoption of that Constitution "was preceded by the most comprehensive process of review and consultation ever carried out in Fiji."16 The CRC was appointed by Parliament, which also drew up the CRC's Terms of Reference: ${ }^{17}$

To produce a report recommending constitutional arrangements which would meet the present and future needs of the people of Fiji; promote racial harmony, national unity and the economic and social advancement of all communities, while at the same time taking into account internationally recognised principles and standards of individual and group rights, guaranteeing full protection and promotion of the rights, interests and concerns of the indigenous Fijian and Rotuman people, and having full regard for the rights, interests and concerns of all ethnic groups in Fiji.

The CRC's Report formed the basis of the 1997 Constitution of Fiji, which was unanimously approved by Parliament and blessed by the Bose Levi Vakaturaga, ${ }^{18}$ or Great Council of Chiefs. The new Constitution received support from all major parties and from civil society. ${ }^{19}$ Like its predecessors, the 1970 and 1990 constitutions, the 1997 Constitution included a Bill of Rights in the form typical of the one included, with some variations, in the constitutions of most former British colonies in the Pacific and elsewhere. ${ }^{20}$

13 Ibid, s 143(1).

14 Each nomination must be approved by the appropriate sector standing committee of the House of Representatives before the Minister submits the nomination to the President. The sector standing committee may confirm or reject a nomination made by the Minister, in which case the Minister may make a fresh nomination; ibid, ss 143(4)-143(6).

15 Ibid, ss 170(1) and 170(2).

16 Brij V Lal "Making History, Becoming History: Reflections on the Alleged Failure of the Fiji Constitution" (2001) 5 Newcastle Law Review 82.

17 Ibid, 85.

18 "The Great Council of Chiefs" established under s 116 of the Constitution.

19 Lal, above n 16, 85-86.

20 This Bill of Rights was based on the European Convention for the Protection of Human Rights and Fundamental Freedoms (4 November 1950) 213 UNTS 222, which was itself based on the Universal Declaration of Human Rights UNGA Res. 217 (III), UN Doc. A/810 (1948) 71 and it protected primarily civil and political rights. 
The CRC anticipated that a NHRI would make a significant contribution to achieving the interracial harmony and consequent political stability that Fiji hoped to attain after the introduction of the 1997 Constitution. ${ }^{21}$ The CRC held the view that a Human Rights Commission could address "the limited public awareness of the Bills of Rights in the 1970 and 1990 Constitutions, as well as the lack of in-depth understanding about the work of United Nations bodies in promoting human rights". ${ }^{22}$ The CRC argued that: ${ }^{23}$

Respect for the Bill of Rights required understanding of its provisions and their origins in the international instruments, as well as understanding and acceptance of the promotional and supervisory role of United Nations bodies and their member states in the international protection of human rights.

The CRC viewed the primary role of a Human Rights Commission to be "in the first instance public education" and then "an advisory function in alerting the government to matters affecting compliance with human rights norms". ${ }^{24}$ It considered that the proposed Human Rights Commission "could also be given the function of making recommendations on the implications of any proposed Act or regulations or other policy of the Government that the Commission considers may affect human rights". ${ }^{25}$ With extraordinary prescience, in light of events after December 2006, the CRC advised that: ${ }^{26}$

This is a role that needs to be exercised with extreme caution. Opinions may legitimately differ on whether proposed way of dealing with a recognised evil is or is not consistent with human rights. That question is properly a matter for public debate. But a body devoted to the protection of human rights should express its concerns only after undertaking adequate research and seeking to ensure that its recommendations will achieve a proper balance between human rights principles and the problem that the government is trying to address. Otherwise its efforts could be counterproductive.

The Fijian Parliament passed the Human Rights Commission Act 1999 ("the Act") to give effect to the provisions of the Constitution establishing the Commission. The Act established a human rights commission with a broad range of powers and duties, including the central functions of providing education about human rights, conducting inquiries and investigations into possible

21 For background on previous military coups see Victor Lal Fiji Coups in Paradise (Zed Books, London, 1990) and Brij Lal and Tomasi Vakatora Fiji in Transition (University of the South Pacific, Suva, 1997).

22 Sir Paul Reeves, Tomasi Rayulu Vakatora and Brioj Vilash Lal The Fiji Islands - Towards a United Future: Report of the Fiji Constitution Review Commission Parliament of Fiji (Parliamentary Paper No 34, 1996) 125.

23 Ibid.

24 Ibid.

25 Ibid.

26 Ibid. 
infringements of human rights, encouraging governmental compliance with Fiji's international human rights obligations, advising Government of the human rights implications of its actions and policies and resolving complaints by conciliation or by referral to the courts. ${ }^{27}$

In relation to the selection of Commissioners, the Act addresses the Paris Principles requirements of pluralism in section 8 . This section provides that regard must be had not only to the personal attributes of members, but also to the desirability of members possessing a diverse range of characteristics such as race, ethnic origin, colour, place of origin, gender, sexual orientation, birth, primary language, economic status, age and disability. ${ }^{28}$ Section $10(1)$ of the Human Rights Act provides that a Commissioner must not actively engage in politics.

\section{THE FIFI HUMAN RIGHTS COMMISSION 1999-2006}

The Director of the FHRC in 2006 was Dr Shaista Shameem, who had held the position since 1999. ${ }^{29}$ Dr Shameem stated "at its inception in 1999, the FHRC concentrated on its education function, publishing pamphlets and conducting workshops and training for trainers and human rights activists as well as police and prison authorities". ${ }^{30}$ After George Speight's abortive coup in 2000 and the state of emergency that followed, the FHRC continued its work amidst budget cuts and security issues. ${ }^{31}$ However, the FHRC continued to function, focussing its attention on

27 Human Rights Commission Act 1999, s 7.

28 Human Rights Commission Act 1999, s 8 provides:

In advising the President as to the persons to be appointed as members of the Commission pursuant to section 42 of the Constitution, the Prime Minister must have regard not only to their personal attributes but also to-

their knowledge or experience of the different aspects of matters likely to come before the Commission; and

the desirability of having as members of the Commission persons with a diversity of the personal characteristics referred to in subsection 38 (2) of the Constitution.

Section 38(2) of the Constitution prohibits discrimination against any person on the ground of his or her

Actual or supposed personal characteristics, including race, ethnic origin, colour, place of origin, gender, sexual orientation, birth, primary language, economic status, age or disability" or

opinions or beliefs, except to the extent that those opinions or beliefs involve harm to others or the diminution of the rights or freedoms of others.

29 The FHRC has a full-time Director who oversees the Commission's operations. Dr Shaista Shameem was appointed Director of the FHRC in 1999 and now holds the position of Chairperson; the appointment is referred to in the Fiji Human Rights Commission's publication 6 (3) Rights Quarterly (September 2007).

30 Shaista Shameem The Fiji Human Rights Commission (Osaka, Hurights, 2001) www.hurights.or.jp (accessed 6 August 2008).

31 Ibid. 
"investigating allegations of human rights violations and breaches of the Bill of Rights by the police, military and prison authorities during the state of emergency". ${ }^{32}$ Dr Shameem stated in 2001 that: $^{33}$

The Commission's close association with the Asia Pacific Forum for National Human Rights Institutions assists it in keeping in mind international human rights law as well as fosters the human rights practice in Fiji that is specific to our own special circumstance as a Pacific Island State with a unique multiethnic culture.

By 2002, Dr Shameem was able to claim that "the Commission had dealt with just about every single right protected in Chapter Four of the Constitution". ${ }^{34}$ Notable amongst its achievements was successfully arguing that the sentence of the convicted leader of the May 2000 civilian coup, George Speight, should be commuted from the death penalty to life imprisonment. The FHRC was also successful in lobbying Parliament to have the death penalty removed from the penal code. ${ }^{35}$

The FHRC appears to have been energetic in fulfilling its mandate to protect and promote human rights at the domestic level. In 2006 the FHRC Complaints Unit reported dealing with twenty-two cases concerning human rights issues such as the right to legal counsel, the right to equality on the ground of sexual orientation; cruel, degrading and inhuman treatment by police officers; and constitutional redress applications by prisoners who complained about their conditions in prison and holding cells. ${ }^{36}$ In its 2006 Report to the APF, the FHRC detailed a programme of public education that included developing a human rights intervention curriculum for schools from pre-school to Form Seven, community education programmes and community consultations. ${ }^{37}$ The FHRC reported receiving requests from the Government and Parliamentary select committees for submissions on several Bills, such as the Prisons and Corrections Bill, Financial Management Bill, Employment Relations Bill and the Reconciliation and Unity Bill. The FHRC reported that: ${ }^{38}$

32 Ibid.

33 Ibid.

34 Shaista Shameem "The Challenge for a Genuinely Free Press in the Pacific" (2002) Pacific Journalism Online www.usp.ac.fj/ (accessed 6 August 2008)

35 Country Report of Fiji Delivered at the Seventh Annual Meeting of the Asia Pacific Forum of National Human Rights Institutions (Delhi, India, 13 November 2002). An overview of the protection function of the FHRC, written by Dr Shameem, is provided in Bertrand G Ramcharan (ed) The Protection Role of National Human Rights Institutions (Martinus Nijhoff, Boston, 2005) 43-56.

36 Ibid

37 Fiji Human Rights Commission Fiji Human Rights Commission Annual Report to APF (2006).

38 Ibid. 
These bills were revised quite substantially subsequent to our submissions and we have agreed with the recommendations of the select subcommittees for their amendments in compliance with the Bill of Rights provisions in our Constitution.

By 2006, the FHRC had established its credentials as an independent and effective human rights commission.

Perhaps the most controversial aspect of the FHRC's work before the assumption of military power by Commander Bainimarama in December 2006, was the Commission's June 2006 Report on Government's Affirmative Action Programmes, 2020 Plan for Indigenous Fijians and Rotumans and the Blueprint. In this report, the FHRC concluded that the Government of Prime Minister Laisenia Qarase had breached provisions of the 1997 Constitution, which guarantees freedom from unfair discrimination ${ }^{39}$ and requires that affirmative action programmes be designed to achieve effective equality of access to "all groups or categories of persons who are disadvantaged". ${ }^{40}$ The FHRC argued that the steps taken by the Government to address the poverty of indigenous Fijians (which included granting Government contracts to indigenous Fijians and restricting Indo-Fijians from Government-sponsored business opportunities), ${ }^{41}$ "failed to make provision for all who are disadvantaged". ${ }^{42}$ The Commission's Report drew particular attention to the fact that the Government programmes failed to make provisions in relation to women, who suffered greater disadvantage that men and stated that "[i]ndividual programmes are weighed so disproportionately against Indians, women and other disadvantaged groups as to undermine the legality of all the programmes based on ethnicity." 43 Commentators such as Kevin Chang have supported the FHRC's indictment of the Government's affirmative action plans, arguing, "one core problem of the affirmative action program lay in its simplistic connection between poverty and ethnicity and its implication that all indigenous Fijians are disadvantaged". ${ }^{44}$

In a press conference held on 30 June 2006 in order to respond to the FHRC Report, Prime Minister Qarase stated, "the Commission has not properly discharged its responsibilities, and has

39 The Constitution (Fiji), s 38(2).

40 Ibid, s 44(1).

41 Kevin Chang "After the Storm of 2000: Fiji's Troubled Path Toward Justice and Reconciliation" in Wilmar Salim and Kiran Sagoo (eds) Sustaining a Resilient Asia-Pacific Community (East-West Centre and Cambridge Scholars Publishing, 2008) 119, available at http://ssrn.com/abstract=1136486 (accessed 1 June 2008).

42 Fiji Human Rights Commission Report on Government's Affirmative Action Programmes, 2020 Plan for Indigenous Fijians and Rotumans and the Blueprint (2006) 4.

43 Ibid, 4.

44 Chang, above n 41, 16. 
sowed seeds of division at a time when we are trying to build harmony and unity in the nation."45 The Prime Minister affirmed the Government's commitment to helping the disadvantaged of all communities, stating: 46

Affirmative action is central to our mission of creating a stable and harmonious country. Virtual exclusion of Fijians from major sectors of the economy was a big factor in what occurred in 1987 and 2000. We do not want that to happen again. That is why we are determined to remove long-standing disparities in society and the economy, defined largely on ethnic lines.

In a 2007 report, the Fiji Human Rights Commission drew a link between "the Government's condemnation of the Commission's report on Affirmative Action policies and the announcement of snap elections". ${ }^{47}$ Elections were announced in March 2006 and scheduled to be held in May of that year, at a time which, in the Commission's view, "Fiji was far from ready for elections". ${ }^{4}$ The Commission pointed out that the last census had been conducted in $1996^{49}$ and since then there had been no review of the boundaries of constituencies to determine whether or not they should be changed to give effect to the provisions of the Constitution that allow for representation along ethnic lines. ${ }^{50}$ This is one of the reasons why the validity of the 2006 election was questioned by the

45 Statement of Prime Minister Qarase (30 June 2006) Press Conference available at www.fiji.gov.fj/publish/printer_6976.shtml (accessed 1 June 2008).

46 Ibid. The reference to "what occurred in 1987 and 2000" is a reference to the military coups (or attempted coups) of those years.

47 Shaista Shameem The Assumption of Executive Authority on December $5^{\text {th }} 2006$ by Commodore J V Bainimarama, Commander of the Republic of Fiji Military Forces: Legal, Constitutional and Human Rights Issues (4 January 2007) available at www.humanrights.org.fj/ [Shameem Report].

48 Ibid, 7.

49 Ibid.

50 Of the 71 seats in Parliament, 23 are reserved for ethnic Fijians, 19 for Indians, 1 for a Rotuman, 3 seats for those who are not Fijian, Indian or Rotuman and the rest of the seats, 25 in total, are open for voters from all communities. The FHRC stated that "in both 2001 and 2005, election results in Fiji were determined by the Open seats": ibid, 8. 
FHRC, ${ }^{51}$ and its victors declared by others (such as Commodore Bainamarama, then head of the armed forces) to be corrupt. ${ }^{52}$

On 5 December 2006, Commadore Bainimarama assumed executive power and dismissed President Ratu Josefa Iloilo, Vice-President Ratu Joni Madraiwiwi and Prime Minister Laisenia Qarase. On 4 January 2007 Commodore Bainimarama restored executive authority to President Iloilo, who on 5 January 2007 appointed Commodore Bainimarama as interim Prime Minister.

\section{THE FIJI HUMAN RIGHTS COMMISSION IN THE AFTERMATH OF THE EVENTS OF DECEMBER 2006}

By 2007, the Fiji Human Rights Commission was widely perceived by domestic and international aid organisations and the foreign media to have compromised its independence by giving overt support to what most legal commentators have described as the coup d'état of Commodore Bainimarama in December 2006. ${ }^{53}$ Although both the ICC and the APF commenced reviews of the status of the FHRC, the FHRC resigned from APF and withdrew from the ICC before these bodies could reach a conclusion on whether the FHRC still complied with the Paris Principles requirement of independence from Government.

Two aspects of the FHRC's conduct in the aftermath of the events of December 2006 caused the international community - and in particular the APF and ICC - to question the FHRC's independence from the ruling power. The first was the method of appointment of the Acting Ombudsman, Rodney Acraman, by the military Government in December 2006. The position of Ombudsman had been vacant for over six months while the Constitutional Offices Commission deliberated on its appointment recommendation. Following the seizure of power by the military, Commadore Bainimarama dismissed the Acting Chairperson of the Constitutional Offices

51 The Assumption of Executive Authority on December $5^{\text {th }} 2006$ by Commodore J.V. Bainimarama, Commander of the Republic of Fiji Military Forces: Legal, Constitutional and Human Rights Issues Part II: Report to the UN High Commissioner for Human Rights on alleged breaches of international law and the 1997 Constitution of Fiji in the removal of the Prime Minister, Laisenia Qarase on December $5^{\text {th }} 2006$ (29 August 2007) available at www.humanrights.org.fj (accessed 1 June 2008) [Shameem Report Part II].

Dr Shaista Shameem states at p 2: "The [first] Reports also stated that second Qarase Government had failed to hold a census to enable constituency boundaries to be constitutionally drawn prior to the 2006 elections. The validity of both Qarase Governments, that is, of 2001 and 2006, was therefore questioned."

52 Chang, above n 4, 21.

53 "Report Claims Military Abuse" Fiji Times Online (8 March 2007) www.fijitimes.com (accessed 21 August 2008). A United States State Department report on human rights practices in Fiji has criticised FHRC Director Dr Shaista Shameem for failing to publicly object to human rights abuses: Department of State Country Practices on Human Rights 2007 (2008) "Fiji" www.state.gov/ (accessed 15 December 2008). The Australian Minister for Foreign Affairs labelled the Director of the FHRC an apologist for the Fiji military regime: Hon Alexander Downer, Australian Minister for Foreign Affairs (1 March 2007) Media Release www.foreignminister.gov.au/releases/2007 (accessed 21 August 2008). 
Commission, Stuart Huggett. ${ }^{54}$ Then, in his capacity as Acting President, Commadore Bainimarama appointed Mr Acraman as Acting Ombudsman, ${ }^{55}$ by-passing the constitutional requirement that the Ombudsman be appointed by the Constitutional Offices Commission following consultation with the Prime Minister. ${ }^{56} \mathrm{Mr}$ Acraman then became, by default, Acting Chairperson of the FHRC. On 14 December 2007, one of the other two Commissioners of the FHRC, Sevuloni Valenitabua, resigned in protest at Mr Acraman's appointment. The other Commissioner, Shamima Ali, retained her position.

The second aspect of concern involved the Commission's January 2007 report (the Shameem Report) on the military coup. ${ }^{57}$ Dr Shameem, who authored the report as Director of the FHRC, stated that it was written "in response to the number of requests the Commission has received from the public to determine legality issues" 58 and was based on: ${ }^{59}$

\footnotetext{
An assessment of the Commander's assumption of executive authority as well as on the apparently singular view of both local and international observers and commentators that the Commander of the RFMF illegally overthrew the democratically elected and legitimate Government of Fiji on December 5 2006.
}

The Shameem Report received the imprimatur of the Chair of the Commission, Mr Acraman, although it appears that it had been written before his term of office began. The Report stated, "the Qarase Government was involved in massive violations of human rights in Fiji, constituting crimes against humanity, and made serious attempts to impose ethnic cleansing tactics in Fiji." 60 It further stated that, "the crimes against humanity that were committed in Fiji 2001 - 2006 were condoned not only by the non-governmental organisations (NGOs) but also by UN agencies". ${ }^{61}$

The Shameem Report's legal analysis of the assumption of power by Commodore Bainimarama was that it was justified under the doctrine of necessity; the Commadore "stepped into the President's shoes" to remove the Prime Minister and to dissolve Parliament. ${ }^{62}$ According to the

54 Dr Shameem stated that the reason given for the dismissal of Mr Huggett was that he was placed in a situation of conflict of interest in breach of s156 of the Constitution: Shameem Report, above n 47, 20.

$55 \mathrm{Mr}$ Acraman, for sixteen years Secretary to the Ombudsman's office, had been one of the applicants for the position of Ombudsman.

56 The Constitution (Fiji), s 163(1).

57 Shameem Report, above n 47. See also Shameem Report Part II, above n 51.

58 Shameem Report, above n 47, 2.

59 Ibid.

60 Ibid, 15.

61 Ibid.

62 See Republic of the Fiji Islands v Chandrika Prasad [2001] FJCA 2 and cases cited there. 
Shameem Report, the Royal Fiji Military Forces (RFMF) "overthrew an illegally constituted, unconstitutional Government which was acting against the public interest in violation of public security and public safety protections in the Constitution". 63 The Report stated that the RFMF had the "capacity to invoke certain human rights and welfare powers under section 94 of the 1990 Constitution and section 112 of the 1997 Constitution Amendment Act"64 and that: ${ }^{65}$

Since it has the constitutional power to ensure security and protect people, the military does not act unlawfully as long as it keeps to this objective. In view of the rampant abuse of power, privilege, illegalities and wastage of wealth of the Qarase regime, as well as its proposed discriminatory legislation which, if enacted, would have constituted a "crime against humanity" under the International Law Commission's definition, and limited scope for an immediate judicial solution, there appear to few options remaining to protect the people of Fiji from an illegal, unconstitutional, anti-human rights, and despotic regime.

The Shameem Report also contained a "compliance audit" of the effect of the military takeover on the Bill of Rights provisions in the 1997 Constitution. The "audit" concluded that "in the Commission's assessment of events in the early stages, few of the rights in the Bill of Rights provisions were derogated from by the Commander to the extent of Chapter 14 requirements, ${ }^{66}$ though concerns were raised in the first week about a number of people being taken to the army camp for questioning". ${ }^{67}$ The Report noted that one person, Kenneth Zinck, "was reported to have been treated with an indignity during this early period"68 and that the Editor in Chief of a local newspaper was intimidated and physically abused, ${ }^{69}$ but that the exercise of rights such as freedom of movement, personal liberty, freedom of association and privacy, remained generally unaffected. ${ }^{70}$

63 Shameem Report, above n 47, 30.

64 Ibid, 6.

65 Ibid, 31.

66 The Constitution ch 14 contains provisions relating to procedures to be followed during a state of emergency. It allows authorities to derogate from certain rights protected by the Bill of Rights, "if Cabinet has reasonable grounds for believing that, because of the emergency described in the proclamation of the state of emergency, the life of the state is threatened and the exigencies of the situation are such that they cannot be dealt with effectively without derogating from the Bill of Rights": Shameem Report, above n 47, 17.

67 Ibid.

68 Ibid.

69 Ibid, 18.

70 Ibid. 
The Shameem Report noted that (some) constraints had been imposed by the military on freedom of expression and freedom of assembly, ${ }^{71}$ but also noted that these rights "were limited even in normal times by national security, public safety and public order law...."72 The Commission itself: 73

Thought it wise, in the interests of public safety, to bluntly remind people of the limitation clauses in the Bill of Rights, especially as some of the protestors appeared to the Commission investigators to be deliberately antagonizing the military and justifying their acts on the fact that the Constitution was still in place.

The assessment in the Shameem Report of the nature and extent of human rights violations committed in the wake of the assumption of military rule is in marked contrast to the assessment made by representatives of international NGOs and outside observers. Amnesty International, for example, reported "deaths in custody, degrading punishment of government opponents and crackdowns on the judiciary and media," with the military responsible for "limiting the judiciary's independence and severely undermining media freedom and freedom of expression." 74

A response to the Shameem Report was drafted and circulated in January 2007 by Commissioner Shamima Ali "and a group of respected senior lawyers who between them have considerable experience and expertise in human rights and constitutional law nationally and internationally". ${ }^{75}$ The response queried the authority of the Shameem Report in light of the fact that the Acting Chair of the FHRC had not been legally and constitutionally appointed. It also addressed the substance of the report, particularly the report's assertion that the military acted lawfully in seizing power in December 2006: ${ }^{76}$

It is in the Report's support for the role of the RFMF under the 1990 Constitution that discloses its slant. It goes to extraordinary lengths to put a gloss on the military having an expanded brief in normal life. The explanation may have a reassuring feel among those who have applauded their recent actions. One succumbs to this delusion at his/her peril. This country has had four coups. All have had their genesis in the RFMF with some participation from outside elements. It is an armed military commanded by

71 Shameem Report, above n 47, 19.

72 Ibid.

73 Ibid.

74 "Amnesty International: Fiji human rights on downward spiral since military coup" International Herald Tribune (29 May 2008) www.iht.com/articles (accessed 16 December 2008).

75 Shamima Ali A Response to the Fiji Human Rights Commission Director's Report on the Assumption of Executive Authority by Commodore J V Bainimarama, Commander of the Republic of Fiji Military Forces available at www.dev-zone.org/ (accessed 18 August 2008) [Ali Report]. Shamima Ali's term as Commissioner has now expired.

76 Ibid, 12 
officers who arrogate to themselves the role of watchdog, for no other reason than their possession of guns that remain a constant threat to our fledgling democracy.

Commissioner Ali's response concludes: ${ }^{77}$

The Report is riddled with legal inaccuracies, misapplications of the law and a selective reading of case law. What is disturbing is that it claims to be a dispassionate and balanced analysis of the legalities surrounding the RFMF's usurpation of power on 5 December 2006. It is in fact a veiled justification for the actions of the RFMF on 6 December 2006. What emerges from the Report is a pathological dislike of Prime Minister Qarase and his two governments. The tragedy is that in confusing the latter with its apparent approval of the RFMF's perspective in relation to its own actions, the Report has compromised the Fiji Human Rights Commission and Shameem's own standing as well as set back the cause of human rights generally in Fiji.

This paper does not aim to resolve the Shameem/Ali debate. Some of Shameem's contentions are inflammatory, such as her statement that: ${ }^{78}$

Democracy is still very much at an experimental stage internationally, and the Human Rights Commission acknowledges that as long as there is representation of all the people in governance, any kind of human rights respecting democracy would be acceptable. It is reminded of the fact that Hitler won both an election and a plebiscite before 1939, and survived a military putsch. The price of Hitler's democracy was 11 million people dead in the death camps.

Such comments tend to obfuscate the fact that many people in Fiji shared Shameem's view that the events of 2006 were a correction to the political situation imposed after the 1987 and 2000 coups. ${ }^{79}$ Jon Fraenkel writes that, other than the Director of the Fiji Human Rights Commission: ${ }^{80}$

An assortment of Catholic social justice advocates, much of the business community and probably the majority of left-leaning civil society activists supported the coup... the reaction from the bulk of the

77 Ali Report, above n 75, 13.

78 Shameem Report, above n 47, 32.

79 On 9 October 2008, Acting Chief Justice Gates and Justices Byrne and Pathik of the High Court of Fiji found that President Iloilo had acted lawfully following Commander Bainimarama's seizure of power. The Court held that "exceptional circumstances existed, not provided for by the Constitution and the stability of the State was endangered. We also find that no other course of action was reasonably available, and that such action as taken by the President was reasonably necessary in the interests of peace, order and good government." Qarase v Bainimarama [2008] FJHC 241 para 162. The Fiji Human Rights Commission acted as amicus curiae, although the case turned largely on issues of constitutional law relating to the prerogative powers of the President and the doctrine of necessity, and the judgment makes no explicit reference to human rights issues.

80 Jon Fraenkel "The Fiji Coup of December 2006: who, what, where and why?" Addendum in Jon Fraenkel and Stewart Firth (eds) From election to coup in Fiji: The 2006 campaign and its aftermath (ANU Epress, 2007) 420 http://epress.anu.edu.au/ (accessed 8 August 2008). 
Fijian Indian community was astonishing; the group that had such a strong sense of its own victimhood, due to the 1987 and 2000 coups and the much earlier experience of girmitya (indentured labour), was strongly in favour of the clean-up coup.

The dispute between the Director of the FHRC and its remaining legally appointed Commissioner brought the FHRC into disrepute and demanded the attention of the APF and the ICC. Initially, the Director of the FHRC actively sought counsel and support from the APF. The Director made members of the network aware of the irregular process used to appoint Mr Acraman and offered to resign or withdraw from the APF and ICC if the membership held the view that this was the appropriate course of action for the FHRC to pursue. The APF and ICC commenced enquiries into the question of whether the irregularities of Mr Acraman's appointment jeopardised the FHRC's compliance with the Paris Principles requirements of independence. The APF commenced a formal review of the FHRC on 20 March 2007. On 3 April 2007, the FHRC resigned from the APF. On 22 March 2007, the ICC suspended the "A" status of the FHRC pending provision of information by FHRC about its independence. Soon after, the FHRC also resigned from the ICC.

The irregularity in appointment of the chairperson and the dispute between the FHRC's Director and one of its Commissioners undermined the credibility of the FHRC during a period when the human rights of Fiji's citizens were gravely threatened. The narrower issue is whether there were structural flaws in the constitutional and legislative provisions relating to appointment of Commissioners and Commission staff that opened up space for such a dispute to occur. The broader issue concerns the political nature of the FHRC's report and the response to it from the APF and ICC.

\section{THE "POLITICISATION" OF THE FHRC?}

The events of December 2006 and the subsequent conduct of the FHRC raise questions about the FHRC's independence and operation: how does a human rights commission fulfil its duty to discuss the human rights implications of political actions without the appearance of partisanship? Is it possible for a NHRI to support government policy or action without losing its real or perceived independence? Ought the constitutional and legislative safeguards that aim to ensure the appointment of apolitical, bipartisan, representative commissioners be employed in the selection of high level commission staff, as well? Is the appointment of "part-time" commissioners, or commissioners with other primary obligations, the most effective way of ensuring the integrity of a NHRI? This article does not attempt to provide definitive answers to these questions, but rather aims to explore some of these issues in the context of the FHRC's experience following the events of December 2006.

The experience of the FHRC illustrates the difficulties a national commission experiences as it attempts to carry out its functions in a complex and turbulent socio-political terrain. It would be naïve to suggest that a national commission must be apolitical. Its mandate is to monitor the extent 
to which the population of the state enjoy their human rights. The reports, findings and investigations of a national commission will in many instances address political issues of interest to the broader community, and their reports and recommendations may have political consequences. Governments may adopt the recommendations of a national report or reject them; opposition parties may use the national commission's work to gain political advantage or to extract political concessions, and NGOs may use the work of the NHRI as leverage to secure undertakings from government. Indeed the effectiveness of a NHRI - the degree to which its work influences government policy to achieve human rights advances - may depend upon on the degree to which the NHRI is perceived as having direct or indirect political influence and impact. A commission that fails to address fundamental human rights issues embedded in the pressing political issues of its nation is likely to be viewed as an ineffectual commission.

The Paris Principles state that "a national institution shall be given as broad a mandate as possible, which shall be clearly set forth in a constitutional or legislative text, specifying its composition and its sphere of competence." ${ }^{81}$ Leaving to one side the question of whether the Shameem Report was the work of the FHRC or merely of an individual employee acting beyond her authority, the report's attempt to portray the seizure of power by the military in 2006 as legal under international law has been condemned as an unacceptable foray by a NHRI into the realm of the political. ${ }^{82}$ Condemnation of the particular tenor of the Shameem Report - which supported the extra-constitutional removal of an elected government - has distracted commentators from reflecting upon the more basic question of whether or not it is the role of a NHRI to express views on overtly political matters such as the legitimacy of the imposition of martial law. ${ }^{83}$

The Fiji Human Rights Commission Act, laudable in the breadth of its mandate from a Paris Principles perspective, empowers the FHRC to inquire generally into any matter, including any enactment or law, or any procedure or practice whether governmental or non-governmental, if it appears to the Commission that human rights are, or may be, infringed thereby and to investigate allegations of contraventions of human rights and allegations of unfair discrimination, of its own

81 Paris Principles, above n 3.

82 For example "the FHRC has been perceived as losing its independence and credibility over the past 10 months, especially in light of its controversial legal analyses of the December 5th 2006 military coup in Fiji. A controversial report, released in January 2007, justified the coup as a necessity to protect Fiji from possible 'crimes against humanity' by the elected government." Press Release (17 October 2007) www.fijiwomen.com/index (accessed 21 August 2008).

83 Commentators have discussed the difficulty NHRIs have in establishing independence from Government and the loss of credibility that follows when NHRIs make concessions to Government - see, in particular, Anne Smith's discussion of the Northern Ireland Human Rights Commission: Anne Smith "The Unique Position of Human Rights Institutions: A Mixed Blessing?" (2006) 28 Human Rights Quarterly 904. 
motion or on complaint by individuals, groups or institutions on their own behalf or on behalf of others. ${ }^{84}$

The Shameem Report arguably fell within the jurisdiction of the FHRC, and the report seeks to ground its arguments in human rights analysis. If the Shameem Report was within the mandate of the FHRC, to what extent ought its substance become the subject of review by the APF and ICC? If "the practical task of protecting and promoting human rights is primarily a national one, for which each state must be responsible" 85 and "the most effective education and information campaigns are likely to be those which are designed and carried out at the national or local level and which take the local cultural and traditional context into account" 86 then surely a great deal of discretion must be allowed for national commissions to exercise their mandate as they see fit. A human rights commission must be able to occasionally endorse the actions of the Government of the day, if in its view these actions further people's enjoyment of human rights, without necessarily acquiring the label of "puppet" or "lackey".

In what sense did the FHRC's (the Shameem Report) about Commodore Bainimarama's assumption of power indicate that the FHRC was no longer independent? There are a number of possible responses to this question. One is that NHRIs are established under a protocol endorsed by the UN, which is an institution committed to the promotion of a particular form of western democracy. Ipso facto, NHRIs cannot act to undermine or question the legitimacy of democratic processes such as periodic elections that are endorsed by the UN. The Shameem Report argues "the RFMF overthrew an illegally constituted, unconstitutional Government which was acting against the public interest in violation of public security and public safety protections in the Constitution." ${ }^{87}$ Outside observers were unable to accept as credible an "independent" interpretation of events so at odds with that of most UN observers and international NGOs. The inference that was drawn was that the FHRC was acting in support of the ruling power on the basis of an implausible human rights analysis, and was hence not independent of the military government in appearance or in substance.

An alternative response is that the Shameem Report reveals its author's fundamental misconception of the role of a NHRI. In the report, Shameem writes, "the Human Rights Commission has a constitutional responsibility, as a neutral and impartial broker, to defend human rights." 88 In the notion of "broker" Shameem touches upon a key component of a commission's role: responsibility and accountability to a range of social and political actors. A NHRI is required to

84 Human Rights Commission Act 1999, s 7.

85 Office of the High Commission for Human Rights Factsheet No. 19 National Institutions for the Promotion and Protection of Human Rights www.unhchr.ch/html/menu6/2/fs19.htm (accessed 21 August 2008).

86 Ibid

87 Shameem Report, above n 47, 31.

88 Ibid, 27 
engage with the executive, with legislators, with the judiciary, with civil society and NGOs, with the media, and with members of the international community. In carrying out its role of protecting and promoting human rights, it cannot succumb to pressure from any one of these groups. Its aim must be to engage with each group in an open and approachable manner and to promote dialogue between these groups on human rights subjects.

A NHRI will only be able to achieve this if there is a perception by these groups (as well as the reality), that it is driven solely by its mandate to improve the standard of human rights enjoyed by the community. Particularly in situations of extreme political sensitivity, such as after a military takeover, the legitimacy of a NHRI will depend on whether it stands as a credible commentator on violations of human rights that may be occurring. Its credibility will be undermined if the institution publicly endorses a particular political party, movement or action.

The FHRC Director's singular response to the events of 5 December 2006 was so weighted toward vindication of the actions of Commadore Bainimarama that it excluded the FHRC's future engagement on the subject with what the Paris Principles refer to as the pluralist representation of the social forces of civilian society - NGOs, trade unions, concerned social and professional organisations and academics, who may not have agreed with the Shameem Report's interpretation of events.

Regardless of whether the substance of the Shameem Report was correct, its existence compromised the FHRC's ability to fulfil its mandate to engage with all aspects of Fijian society. A requirement of pluralism means more than ensuring an appointment representative of various genders, races and religions; it means a commission comprised of members with the ability to understand and respond to the needs and interests of all aspects of society.

The willingness of a NHRI to criticise the Government has been described as the "litmus test" of its independence. ${ }^{89}$ The experience of the FHRC suggests that independence is more than this; not only must a national institution for the protection and promotion of human rights resist yielding to pressure from any one sector of society, but it must maintain the appearance of impartiality so that it can continue to engage with different parts of society. This will inevitably mean that national institutions will have to withdraw from, or address in sensitive and muted tones, some issues that are highly politicised. The judgments involved here are sensitive but essential to the NHRI maintaining its accountability to Government, to civil society and to the public.

\section{PROCESSES FOR THE SELECTION OF COMMISSIONERS}

The manner in which the FHRC became politicised and lost the appearance of independence in relation to the military Government gives rise to questions about whether there were other ways in which this may have been prevented. One area is in relation to the appointment of commission staff.

89 Smith, above n 82, 936. 
While the Paris Principles address the issue of pluralism generally and in the composition of a NHRI itself, a similar argument might be made in relation to the (senior) staff of a commission. Another issue is whether there needs to be a number of full-time commissioners in order to ensure the effective functioning of a commission and compliance with the Paris Principles.

In the case of Fiji, the constitutional provisions aim to ensure that the people, through Parliament and the President, are represented by Commissioners who are able to recognise and respond to their needs. It could be argued that if a Commission's Chairperson has another primary role (for example the role of Ombudsman) and other Commissioners are part-time appointments, then it is inevitable that much of the direction of a Commission will be determined by its Director or senior executive officers. Unlike Commissioners, senior staff of the Commission do not have fixed terms and are not directly accountable to legislative or executive representatives. It may be the case that a Human Rights Commission requires a dedicated full-time Commissioner or Commissioners and that the "control and direction" provisions of the Human Right Commission Act need to be articulated in greater detail. Of course in the case of Fiji, these tensions were exacerbated by the fact that the position of Chair of the Commission had been vacant for six months or more.

The question of whether Commissioner appointments should be full-time or part-time has been raised in the context of other human rights commissions in the Asia-Pacific region. The Asian NGOs Network on National Institutions (ANNI) publishes a yearly report on NHRIs in the region. In 2008, the ANNI report in relation to the Indonesian Human Rights Commission, Komnas HAM noted, "public confidence has been further eroded because most Commissioners do not work fulltime for Komnas HAM. Some attend only the plenary sessions... they consider their contributions as merely a 'side job."'90 The ANNI report in relation to Malaysia noted that: ${ }^{91}$

Eighteen commissioners are serving out the 2006 - 2008 term. Most are either former civil servants or those who have worked closely with the government. Despite being paid a handsome salary and allowances, the commissioners continue to serve on a part-time basis and are not exclusively focussed on human rights work.

It may be the case that full-time commissioners, whose sole responsibility is to fulfil the national institution's legislative or constitutional mandate, would ensure a more effective and reliably functioning national commission. At its October 2007 session, the International Coordinating Committee's Sub-Committee on Accreditation (the "Accreditation Sub-Committee") announced in

90 The Asian NGOs Network on National Institutions 2008 Report on the Performance and Establishment of National Human Rights Institutions in Asia (Asian Forum for Human Rights and Development, Bangkok, 2008) 77.

91 Ibid, 97. 
one of its General Observations that members of NHRIs should include full-time remunerated members in order to: ${ }^{92}$

a) Ensure the independence of the NHRI free from actual or perceived conflict of interests;

b) Ensure a stable mandate for the members; and

c) Ensure the ongoing and effective fulfilment of the mandate of the NHRI.

It is possible that a laudable desire to meet Paris Principles requirements of pluralism has motivated some states to create commissions with a number of part-time commissioners. However, the Paris Principles pluralism requirements do not necessarily demand a representative selection of commissioners, merely that there be a procedure for selection of members that affords "all necessary guarantees to ensure the pluralist representation of the social forces (of civilian society) involved in the promotion and protection of human rights". ${ }^{93}$ It is possible that a selection committee for commissioners that was representative of different aspects of society, gender, age, religion, academe, and civil society could approve a selection that met the Paris Principles' requirements of pluralism.

The Accreditation Sub-Committee has recognised that "there are diverse models of ensuring the requirement of pluralism set out in the Paris Principles". ${ }^{94}$ The Accreditation Sub-Committee provided several examples of the different ways in which pluralism may be achieved through the composition of the national institution, for example: ${ }^{95}$

a) Members of the governing body represent different segments of society as referred to in the Paris Principles;

b) Pluralism through the appointment procedures of the governing body of the National Institution, for example, where diverse societal groups suggest or recommend candidates;

c) Pluralism through procedures enabling effective co-operation with diverse societal groups, for example advisory committees, networks, consultations or public forums; or

d) Pluralism through diverse staff representing the different societal groups within the society.

92 General Observations developed by the Sub-Committee of the International Coordinating Committee of National Institutions for the Protection and Promotion of Human Rights [Accreditation Sub-Committee] (October 2007) http://nhri.net/ (accessed 21 August 2008).

93 Paris Principles, above n 3.

94 General Observations developed by the Accreditation Sub-Committee (October 2006) http://nhri.net/2008/ (accessed 21 August 2008).

95 Ibid. 
The Paris Principles are broad enough to encompass a wide range of ingenuous approaches to satisfying requirements of pluralism and independence of composition. Pacific island nations seeking to establish NHRIs may be able to fashion creative appointment processes that reflect cultural particularities and the diverse components of Pacific society. The Thai Human Rights Commission, for example, consists of members appointed by the King, who have been elected by the Senate from a list of nominees drawn up by a selection committee. The selection committee consists of the President of the Supreme Court, the President of the Supreme Administrative Court, the Prosecutor-General, the Chairman of the Law Council, rectors and representatives from institutions of higher education and representatives of private organisations in the field of human rights. ${ }^{96}$

\section{THE FHRC AND PARIS PRINCIPLES DEMANDS OF ADEQUATE RESOURCING}

Given that the FHRC has resource limits (a situation likely to be faced more acutely by other Pacific Island nations), the question of the extent to which a NHRI should draw on external funds from public or private donors instead of or to supplement Government funding is important. Not only should Governments be seen to, and actually, invest in their NHRI, but too great a reliance on external funding may undermine both the appearance and fact of independence for a NHRI. This issue has arisen in the context of commissions in countries emerging from conflict situations; it gives rise to complex issues and a simple or uniform answer may not be available. ${ }^{97}$

While the Paris Principles make clear that financial autonomy is the basis of an independent NHRI, they are silent on the source of its funding. The Paris Principles state: ${ }^{98}$

The national institution shall have an infrastructure which is suited to the smooth conduct of its activities, in particular adequate funding. The purpose of this funding should be to enable it to have its own staff and premises, in order to be independent of the government and not be subject to financial control which might affect this independence.

96 National Human Rights Commission Act 1999, ss 5 and 8. The Thai National Human Rights Commission, like that of Fiji, struggled to maintain independence after the military coup of September 2006. The President at the time, Professor Saneh Charmarik, commented to the local media the day after the coup that "I do not think it is about progression or regression [of democracy] but about problem solving." Nonetheless, the majority of the eleven full-time Commissioners of the Thai NHRC took steps to stress their independence and maintained that they remained vigilant against abuses of human rights by the military junta. Professor Charmarik "cited these varying responses to the coup as proof that the NHRC remains independent to either agree or disagree with the junta": Asian NGOs Network on National Institutions 2008 Report on the Performance and Establishment of National Human Rights Institutions in Asia (Asian Forum for Human Rights and Development, Thailand, 2008) 190.

97 See for example the discussion in relation to Palestine in Byrnes, Durbach, and Renshaw, above n 6.

98 Paris Principles, above n 3. 
The Accreditation Sub-Committee has elaborated on the funding requirements for NHRIs in one of its General Observations. In April 2008, the Sub-Committee noted that the provision of adequate funding by the state should, as a minimum include: ${ }^{99}$

a) The allocation of funds for adequate accommodation, at least its head office;

b) Salaries and benefits awarded to its staff comparable to public service salaries and conditions;

c) Remuneration of Commissioners (where appropriate); and

d) The establishment of communications systems including telephone and internet.

The Accreditation Sub-Committee also stated that adequate funding should, to a reasonable degree, ensure the gradual and progressive realisation of the improvement of the organisation's operations and the fulfilment of their mandate. ${ }^{100}$ The Accreditation Sub-Committee stated that funding from "external sources, such as from development partners, should not compose the core funding of the NHRI as it is the responsibility of the state to ensure the NHRI's minimum activity budget in order to allow it to operate towards fulfilling its mandate". ${ }^{101}$ The APF Council has adopted an arguably more nuanced approach to the issue of funding, particularly in the case of countries emerging from conflict situations. The Council has considered it significant that NHRIs in countries such as Afghanistan and Palestine request donors to contribute funds to support activities set out in the institution's strategic plans, as opposed to the donors suggesting activities for funding. ${ }^{102}$

While securing adequate funding from Government sources for a NHRI may prove challenging for Pacific nations, the experience of Fiji suggests that it may an important factor in securing long term domestic legitimacy. In 2007, the Fiji Human Rights Commission decided not to accept aid from Australia, New Zealand and the European Union. ${ }^{103}$ This decision followed criticism by Australia and New Zealand of the actions of the FHRC in the wake of the events of December 2006. In a media release published on the website of the FHRC on 12 November 2007, Dr Shameem stated her opinion about the provision of aid: "keep your money, we do not want a slush fund and we want to retain our independence". ${ }^{104}$ Dr Shameem stated that "I have been uncomfortable about

99 ICC (20 ${ }^{\text {th }}$ session, Geneva, 14-18 April 2008) http://nhri.net/ (accessed 1 June 2008)

100 Ibid.

101 Ibid.

102 See Byrnes, Durbach, and Renshaw, above n 6.

103 Media enquiry from Maria Burese to Shaista Shameem (12 December 2007) www.humanrights.org.fj/ pdf/ResponseDonor (accessed 21 August 2008).

104 Ibid. 
the NZAID, AusAID and EU power play in the Pacific for some time and we are thankful we need not put up with it any longer". ${ }^{105}$

The comments of Dr Shameem, now the Chairperson of the FHRC, ${ }^{106}$ embody sentiments that to different degrees resonate across the Pacific. A possible alternative to direct financial aid for NHRIs is practical assistance from countries in the region with established NHRIs. This assistance could take the form of the provision of technical expertise, staff training and other capacity-building measures. In this regard, the work of the APF in supporting the establishment of NHRIs in the Asia Pacific region must be noted. As a membership-based organisation, the APF is able to distill the best practices and operational strengths of its members and use them to assist the establishment or development of nascent NHRIs. As a regional organisation, the majority of APF's seventeen members share an ex-colonial past and are sensitive to issues of perceived neo-colonial domination in the guise of the implementation of international human rights. Practical assistance from a membership organisation is likely to be far less offensive to the sensibilities of Pacific nations than other forms of financial assistance. The APF does not employ the concept of "aid" which so caused Dr Shameem to bridle, but creates processes where members share information and resources, develop co-operative partnerships and establish "best practice" standards.

The support of a regional network of NHRIs will be critically important to the national institutions of Pacific nations in less tangible respects as well. It is likely that many of the institutions created in the Pacific would be small, possibly staffed by only one commissioner. It is possible that the institution would be physically dependent on government resources to conduct its work. In such circumstances, members of the human rights institutions would need a robust sense of their own independence from government. Membership of a regional organisation of NHRIs such as APF would assist institution members in identifying with the international human rights community and the norms that it seeks to uphold.

In 2007 the New Zealand Human Rights Commission and the Pacific Islands Forum Secretariat published a study National Human Rights Institutions: Pathways for Pacific States. ${ }^{107}$ The study makes a number of practical suggestions for Pacific nations who may wish to establish a NHRI. These include adopting a "building blocks approach" to the growth of NHRIs: for example, "integrating development into existing planning and budget processes and anticipating short,

105 Media enquiry from Maria Burese to Shaista Shameem (12 December 2007) www.humanrights.org.fj/ pdf/ResponseDonor (accessed 21 August 2008).

106 The appointment is referred to in the Fiji Human Rights Commission's publication 6 (3) Rights Quarterly (September 2007).

107 Joy Liddicoat National Human Rights Institutions: Pathways for Pacific States (Pacific Human Rights Issues Paper No 1, New Zealand Human Rights Commission and the Pacific Islands Forum Secretariat, Fiji and New Zealand, 2007). 
medium and long-term development", 108 "nesting" an NHRI within an existing institution, ${ }^{109}$ and developing a designated human rights capacity such as a "human rights desk". 110

These suggestions retain the State's position as principal provider of funding for national institutions. One of the strengths of a national institution for the promotion and protection of rights, compared to regional or international machinery, is that a national institution is "owned" by the state and its people. It is the peoples' own institution, staffed by nationals with a deep knowledge of the nation, standing watch for the people. For these reasons, while most human rights commissions lack the power to "force" Governments to change policies or amend legislation, nonetheless the recommendations, reports and findings of a NHRI cannot easily be dismissed by governments. The fact that the rights institution is indigenous is a powerful tool for positive coercion of Governments. This tool may be weakened if a NHRI's principal funding is from external sources.

\section{CONCLUSION}

As a growing number of Pacific Island nations ${ }^{111}$ indicate their intention to establish NHRIs, ${ }^{112}$ it is timely to reflect upon the experience of the FHRC. Fiji remains the only Pacific island nation to have created a commission for the promotion and protection of human rights. Fiji has economic resources to support the infrastructure of an independent commission. Its size also means that it has a reasonable pool of talent from which to draw commissioners and staff. Factors other than inadequate economic and human resources led to the demise of the FHRC's reputation as an independent and effective national human rights commission.

The experience of Fiji has shown that regional networks such as the APF and international bodies such as the ICC are prepared to hold NHRIs accountable to preserve the integrity of the Paris Principles. It also shows that the Paris Principles requirements of pluralism and independence, and

108 Ibid, 32.

109 Ibid.

110 Ibid.

111 Nations such as Samoa, the Solomon Islands, Papua New Guinea; above n 2.

112 The Vienna Declaration and Programme of Action, adopted at the World Conference on Human Rights in Vienna (14-25 June 1993) A/CONF.157/23 affirmed that:

The World Conference on Human Rights reaffirms the important and constructive role played by national institutions for the promotion and protection of human rights, in particular in their advisory capacity to the competent authorities, their role in remedying human rights violations, in the dissemination of human rights information, and education in human rights.

The World Conference on Human Rights encourages the establishment and strengthening of national institutions, having regard to the "Principles relating to the status of national institutions" and recognizing that it is the right of each State to choose the framework which is best suited to its particular needs at the national level. 
the relationship that exists between these two concepts, are still largely untested. In aiming to achieving pluralism and independence in practice, NHRIs will be aided by engagement with similar institutions in other states. The experiences of other national human rights commissions will be invaluable aids for nascent NHRIs in the Pacific. Engagement should take place not only at the level of commissioner, but also amongst senior executives, such as directors, managers and chief operating officers, within institutions. Networks such as APF enhance the technical abilities and management capacities of NHRIs, but also serve to reinforce the idea that members and officers of NHRIs are responsible to a regional and international constituency as well as to a domestic one. 
